Supplement of Biogeosciences Discuss., 12, 16431-16477, 2015

http://www.biogeosciences-discuss.net/12/16431/2015/

doi:10.5194/bgd-12-16431-2015-supplement

(C) Author(s) 2015. CC Attribution 3.0 License.

(c) (1)

Supplement of

\title{
Isotopic evidence for biogenic molecular hydrogen production in the At-
} lantic Ocean

\section{S. Walter et al.}

Correspondence to: S. Walter (s.walter@uu.nl)

The copyright of individual parts of the supplement might differ from the CC-BY 3.0 licence. 
Isotopic evidence for biogenic molecular hydrogen production in the Atlantic Ocean Supplement

\section{Due to the experimental upset and timing the following assumption have been made:}

- The glass vessel is initially under vacuum.

- The water sample flows into the glass vessel, equilibrates with the headspace and mix completely with the injected makeup gas.

- No significant exchange between the headspace / makeup gas mixture and the water phase will happen until the sample has been extracted into an evacuated flask.

\section{The following abbreviations and definitions have been used:}

- $V_{\mathrm{h}}$ : volume headspace in the glass vessel $\left(1.6 \mathrm{dm}^{3}\right)$

- $V_{\mathrm{w}}$ : volume water in the glass vessel $\left(8.4 \mathrm{dm}^{3}\right)$

- $V_{\mathrm{t}}$ : volume gas transfer system $\left(0.025 \mathrm{dm}^{3}\right)$

- $V_{\mathrm{f}}$ : volume flask and drying tube $\left(1.1 \mathrm{dm}^{3}\right)$

- $p_{\mathrm{h}}$ : pressure headspace after transfer from Niskin bottle to glass vessel

- $\quad p_{\mathrm{ht}}$ : pressure headspace and gas transfer system before addition of makeup gas

- $p_{\mathrm{htm}}$ : pressure headspace and gas transfer system after addition of makeup gas

- $\quad p_{\mathrm{f}}$ : pressure headspace, gas transfer system and flask after expansion to flask

- $c_{\mathrm{w} 0}$ : initial $\mathrm{H}_{2}$ concentration in seawater

- $c_{\mathrm{h}}: \mathrm{H}_{2}$ concentration in headspace after transfer from Niskin bottle to glass vessel

- $c_{\mathrm{w}}: \mathrm{H}_{2}$ concentration in seawater after transfer from Niskin bottle to glass vessel

- $y_{\mathrm{h}}: \mathrm{H}_{2}$ wet mole fraction in headspace after transfer from Niskin bottle to glass vessel

- $y_{\mathrm{m}}: \mathrm{H}_{2}$ dry mole fraction makeup gas

- $y_{\mathrm{htm}}: \mathrm{H}_{2}$ wet mole fraction in headspace and gas transfer system after addition of makeup gas

- $y_{\mathrm{f}}: \mathrm{H}_{2}$ dry mole fraction sample flask

- $R$ : ideal gas constant $\left(=8.31446621 \mathrm{~J} \mathrm{~K}^{-1} \mathrm{~mol}^{-1}\right)$

- $T$ : ambient absolute temperature (assumed to be equal to the gas temperature)

Defining the extraction efficiency $\boldsymbol{\eta}$ as

$$
\eta=\frac{c_{\mathrm{h}} V_{\mathrm{h}}}{c_{\mathrm{w} 0} V_{\mathrm{w}}}
$$

the initial concentration of $\mathbf{H}_{2}$ in seawater, $c_{\mathrm{w} 0}$, can be calculated from

$$
c_{\mathrm{w} 0}=\frac{c_{\mathrm{h}} V_{\mathrm{h}}}{\eta V_{\mathrm{w}}}
$$

The concentration in the headspace, $c_{\mathrm{h}}$, was not measured directly, but can be derived from the measured $\mathrm{H}_{2}$ mole fraction in the sampling flask. The sampling procedure following gas extraction under vacuum can be broken into three steps (see Methods section):

1. Expansion of headspace

2. Addition of makeup gas

3. Expansion of headspace/makeup gas mixture into sampling flask 
Step 1: The volume of the headspace increases from $V_{\mathrm{h}}$ to $V_{\mathrm{h}}+V_{\mathrm{t}}$, where $V_{\mathrm{t}}$ is the volume of the gas transfer system. The total pressure drops from $p_{\mathrm{h}}$ to $p_{\mathrm{ht}}=p_{\mathrm{h}} V_{\mathrm{h}} /\left(V_{\mathrm{h}}+V_{\mathrm{t}}\right) . \mathrm{H}_{2}$ mole fraction, $y_{\mathrm{h}}$, and isotope delta, $\delta_{\mathrm{h}}$, do not change.

Step 2: Adding makeup gas changes the total pressure from $p_{\mathrm{ht}}$ to $p_{\mathrm{htm}} . \mathrm{H}_{2}$ mole fraction and isotope delta also change. The $\mathrm{H}_{2}$ mole fraction after mixing with makeup gas is:

$$
y_{\mathrm{htm}}=\left(y_{\mathrm{h}}-y_{\mathrm{m}}\right) \frac{p_{\mathrm{ht}}}{p_{\mathrm{htm}}}+y_{\mathrm{m}}
$$

The initial headspace $\mathrm{H}_{2}$ concentration is calculated using the ideal gas law:

$$
\begin{aligned}
c_{\mathrm{h}} & =\frac{y_{\mathrm{h}} p_{\mathrm{h}}}{R T}=\frac{p_{\mathrm{h}}}{R T}\left[\left(y_{\mathrm{htm}}-y_{\mathrm{m}}\right) \frac{p_{\mathrm{htm}}}{p_{\mathrm{ht}}}+y_{\mathrm{m}}\right] \\
& =\frac{1}{R T}\left[\left(y_{\mathrm{htm}}-y_{\mathrm{m}}\right) p_{\mathrm{htm}}\left(1+\frac{V_{\mathrm{t}}}{V_{\mathrm{h}}}\right)+y_{\mathrm{m}} p_{\mathrm{h}}\right]
\end{aligned}
$$

Step 3: The gas is expanded from the manifold into a sampling flask, passing through a drying trap. At this stage the mole fractions are changed due to drying of the gas. The volume of the system also changes, but this affects the $\mathrm{H}_{2} \mathrm{O}$ and $\mathrm{H}_{2}$ mole fractions by the same ratio.

Thus, $y_{\mathrm{htm}}$ is calculated from the measured dry mole fraction in the flask, $y_{\mathrm{f}}$, as

$$
y_{\mathrm{htm}}=y_{\mathrm{f}}\left[1-\frac{p_{\mathrm{h}}\left(\mathrm{H}_{2} \mathrm{O}\right)}{p_{\mathrm{htm}}} \frac{V_{\mathrm{h}}}{V_{\mathrm{h}}+V_{\mathrm{t}}}\right]
$$

where $p_{\mathrm{h}}\left(\mathrm{H}_{2} \mathrm{O}\right)$ is the initial water vapour pressure in the headspace. Due to the short time periods involved $(<4 \mathrm{~min})$, water vapour equilibration is assumed not to occur upon subsequent pressure changes in the system.

Combining equations (2), (4) and (5), the initial seawater concentration can be calculated as

$$
\begin{aligned}
c_{\mathrm{w} 0}= & \frac{\left(y_{\mathrm{htm}}-y_{\mathrm{m}}\right)\left(V_{\mathrm{h}}+V_{\mathrm{t}}\right) p_{\mathrm{htm}}+y_{\mathrm{m}} V_{\mathrm{h}} p_{\mathrm{h}}}{\eta V_{\mathrm{w}} R T} \\
= & \frac{y_{\mathrm{f}}\left[\left(1+\frac{V_{\mathrm{t}}}{V_{\mathrm{h}}}\right) p_{\mathrm{htm}}-p_{\mathrm{h}}\left(\mathrm{H}_{2} \mathrm{O}\right)\right]-y_{\mathrm{m}}\left[\left(1+\frac{V_{\mathrm{t}}}{V_{\mathrm{h}}}\right) p_{\mathrm{htm}}-p_{\mathrm{h}}\right]}{\eta V_{\mathrm{w}} R T}
\end{aligned}
$$

$y_{\mathrm{f}}, y_{\mathrm{m}}, p_{\mathrm{htm}}, V_{\mathrm{t}}, V_{\mathrm{h}}$ and $V_{\mathrm{w}}$ were measured. $R$ is a constant $\left(=8.31446621 \mathrm{~J} \mathrm{~K}^{-1} \mathrm{~mol}^{-1}\right)$.

$T$ is the ambient lab temperature and assumed to be equal to the gas and water temperature. Since ambient lab temperature and surface water temperature were never more than $1.2{ }^{\circ} \mathrm{C}$ apart, this assumption is unlikely to cause and error of more than $0.4 \%$ in $c_{\mathrm{w} 0}$.

$p_{\mathrm{h}}\left(\mathrm{H}_{2} \mathrm{O}\right)$ was assumed to be equal to the equilibrium vapour pressure (calculated following Green \& Carritt $\{, 1967 \# 1602\}$ ) of seawater at temperature $T$ and at its actual salinity, which was measured to within $0.01 \mathrm{~g} \mathrm{~kg}^{-1}$.

The extraction efficiency, $\eta$ can be calculated from the following mass balance

$$
V_{\mathrm{w}} c_{\mathrm{w} 0}=V_{\mathrm{h}} c_{\mathrm{h}}+\alpha V_{\mathrm{w}} c_{\mathrm{h}}
$$


Assuming that headspace and water phase are in equilibrium, the ratio of the $\mathrm{H}_{2}$ concentration in water and in the headspace is given by the Ostwald coefficient

$$
\alpha=\frac{c_{\mathrm{w}}}{c_{\mathrm{h}}}
$$

This gives for the initial concentration in the water

$$
c_{\mathrm{w} 0}=\left(\frac{V_{\mathrm{h}}}{V_{\mathrm{w}}}+\alpha\right) c_{\mathrm{h}}
$$

and for the extraction efficiency as defined in equation (2)

$$
\eta=\left(1+\alpha \frac{V_{\mathrm{w}}}{V_{\mathrm{h}}}\right)^{-1}
$$

In the present case, $\alpha=\alpha\left(\mathrm{H}_{2}\right)$ was equal to $0.0163 \pm 0.0001$, which gives $\eta=92 \%$ for $V_{\mathrm{w}} / V_{\mathrm{h}}=$ $8.4 / 1.6=5.25$.

$p_{\mathrm{h}}$ was not measured and had to be estimated from the gas concentrations in the water.

$$
\begin{aligned}
p_{\mathrm{h}} & =p_{\mathrm{h}}\left(\mathrm{N}_{2}\right)+p_{\mathrm{h}}\left(\mathrm{O}_{2}\right)+p_{\mathrm{h}}(\mathrm{Ar})+p_{\mathrm{h}}\left(\mathrm{CO}_{2}\right)+p_{\mathrm{h}}\left(\mathrm{H}_{2} \mathrm{O}\right) \\
& =R T\left[c_{\mathrm{h}}\left(\mathrm{N}_{2}\right)+c_{\mathrm{h}}\left(\mathrm{O}_{2}\right)+c_{\mathrm{h}}(\mathrm{Ar})+c_{\mathrm{h}}\left(\mathrm{CO}_{2}\right)\right]+p_{\mathrm{h}}\left(\mathrm{H}_{2} \mathrm{O}\right) \\
& =R T\left[\frac{c_{\mathrm{w} 0}\left(\mathrm{~N}_{2}\right)}{\frac{V_{\mathrm{h}}}{V_{\mathrm{w}}}+\alpha\left(\mathrm{N}_{2}\right)}+\frac{c_{\mathrm{w} 0}\left(\mathrm{O}_{2}\right)}{\frac{V_{\mathrm{h}}}{V_{\mathrm{w}}}+\alpha\left(\mathrm{O}_{2}\right)}+\frac{c_{\mathrm{w} 0}(\mathrm{Ar})}{\frac{V_{\mathrm{h}}}{V_{\mathrm{w}}}+\alpha(\mathrm{Ar})}+\frac{c_{\mathrm{w} 0}\left(\mathrm{CO}_{2}\right)}{\alpha\left(\mathrm{CO}_{2}\right)}\right]+p_{\mathrm{h}}\left(\mathrm{H}_{2} \mathrm{O}\right)
\end{aligned}
$$

The extraction efficiencies of all gases were assumed to follow their solubilities. Due to the buffering effect of the $\mathrm{CO}_{2}$ system $\left(\mathrm{CO}_{2}(\mathrm{w}), \mathrm{H}_{2} \mathrm{CO}_{3}, \mathrm{HCO}_{3}{ }^{-}\right.$and $\left.\mathrm{CO}_{3}{ }^{2-}\right)$, the dissolved $\mathrm{CO}_{2}$ concentration changes by only 1 or $2 \%$ during extraction, so that the headspace concentration can be estimated from $c_{\mathrm{w} 0}\left(\mathrm{CO}_{2}\right) / \alpha\left(\mathrm{CO}_{2}\right)$.

$p_{\mathrm{h}}$ was estimated to vary between 98 and $111 \mathrm{hPa}$, with contributions of 46 to $52 \mathrm{hPa}$ from $\mathrm{N}_{2}$, 23 to $27 \mathrm{hPa}$ from $\mathrm{O}_{2}, 1.1$ to $1.3 \mathrm{hPa}$ from $\mathrm{Ar}, 0.4 \mathrm{hPa}$ from $\mathrm{CO}_{2}$ and 17 to $40 \mathrm{hPa}$ from $\mathrm{H}_{2} \mathrm{O}$.

Based on equation (4), the isotope delta of the headspace gas can be calculated as follows

$$
\delta_{\mathrm{h}}=\frac{\delta_{\mathrm{htm}} y_{\mathrm{htm}}\left(1+\frac{V_{\mathrm{t}}}{V_{\mathrm{h}}}\right) p_{\mathrm{htm}}-\delta_{\mathrm{m}} y_{\mathrm{m}}\left[\left(1+\frac{V_{\mathrm{t}}}{V_{\mathrm{h}}}\right) p_{\mathrm{htm}}-p_{\mathrm{h}}\right]}{y_{\mathrm{htm}}\left(1+\frac{V_{\mathrm{t}}}{V_{\mathrm{h}}}\right) p_{\mathrm{htm}}-y_{\mathrm{m}}\left[\left(1+\frac{V_{\mathrm{t}}}{V_{\mathrm{h}}}\right) p_{\mathrm{htm}}-p_{\mathrm{h}}\right]}
$$

Two alternative scenarios were considered to derive the initial isotope delta of dissolved $\mathrm{H}_{2}$, with scenario 1 assuming equilibrium isotopic fractionation between headspace and water, and scenario 2 assuming kinetic isotopic fractionation during extraction from Niskin bottle to glass vessel.

Scenario 1: Correction of $\delta_{\mathrm{h}}$ for equilibrium isotopic fractionation between headspace and water 
The equilibrium isotope fractionation between water and headspace is defined as

$$
\varepsilon=\frac{1+\delta_{\mathrm{w}}}{1+\delta_{\mathrm{h}}}-1
$$

The isotopic mass balance equation between headspace and water can then be described via

$$
V_{\mathrm{w}} c_{\mathrm{w} 0} \delta_{\mathrm{w} 0}=V_{\mathrm{h}} c_{\mathrm{h}} \delta_{\mathrm{h}}+V_{\mathrm{w}} c_{\mathrm{w}} \delta_{\mathrm{w}}
$$

which gives for the isotope delta of the original dissolved gas:

$$
\delta_{\mathrm{w} 0}=\frac{\varepsilon\left(1+\delta_{\mathrm{h}}\right)}{1+\frac{V_{\mathrm{h}}}{V_{\mathrm{w}}} \frac{1}{\alpha}}+\delta_{\mathrm{h}}
$$

The equilibrium isotope fractionation between dissolved phase and gas phase is $\varepsilon=(37 \pm 1) \%$ at $20{ }^{\circ} \mathrm{C}$ [Knox et al., 1992]. The temperature dependence of $\varepsilon$ is unknown and was neglected here.

Scenario 2: Correction for kinetic isotopic fractionation between headspace and water

If kinetic isotope fractionation applies, then the isotopic composition of the residual gas in the water is

$$
\delta_{\mathrm{w}}=\left(1+\delta_{\mathrm{w} 0}\right)\left(\frac{c_{\mathrm{w}}}{c_{\mathrm{w} 0}}\right)^{\varepsilon_{\mathrm{k}}}-1=\left(1+\delta_{\mathrm{w} 0}\right)(1-\eta)^{\varepsilon_{\mathrm{k}}}-1
$$

Then, the isotope delta of the accumulated gas in the headspace is

$$
\delta_{\mathrm{h}}=\left(1+\delta_{\mathrm{w} 0}\right) \frac{1-(1-\eta)^{1+\varepsilon_{\mathrm{k}}}}{\eta}-1
$$

which gives for the isotope delta of the original dissolved gas:

$$
\delta_{\mathrm{w} 0}=\frac{\left(1+\delta_{\mathrm{h}}\right) \eta}{1-(1-\eta)^{1+\varepsilon_{\mathrm{k}}}}-1
$$

The kinetic isotope fractionation during gas evasion is $\varepsilon_{\mathrm{k}}=(-18 \pm 2) \%$ at $20^{\circ} \mathrm{C}$ [Knox et al., 1992]. The temperature dependence of $\varepsilon_{\mathrm{k}}$ is unknown and was neglected here. 